\title{
A hydrostratigraphical approach to support environmentally safe siting of a mining waste facility at Rautuvaara, Finland
}

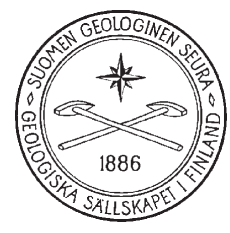

\author{
Peter J. HowetT ${ }^{1)^{*}}$, Veli-Pekka Salonen ${ }^{1)}$, Outi Hyttinen ${ }^{1)}$, \\ Kirsti KorkKa-Niemi ${ }^{1)}$ and Julien MoreaU ${ }^{2)}$ \\ ${ }^{1}$ University of Helsinki, Department of Geosciences and Geography. \\ Finland. P.O.BOX 64 \\ ${ }^{2}$ University of Copenhagen, Department of Geography and Geology. \\ Denmark. P.O.BOX 2177
}

\begin{abstract}
Based on the construction of a detailed sedimentological model, hydrostratigraphy and local groundwater/surface water flows, this paper analyses the Niesajoki river valley as a suitable area for the expansion of a tailings facility, associated with the nearby Hannukainen ( $\mathrm{Cu}, \mathrm{Au}, \mathrm{Fe})$ mine, Finnish Lapland. Three different glacial/interglacial cycles were identified from the sedimentary observations and, optical stimulated luminescence (OSL) datings showed them to be of Early to Late Weichselian in age. Two groups of hydro-stratigraphical units were identified from hydraulic conductivities. The first, fluvial deposits, lie in the centre of the valley along the valley axis, and are the main aquifers. The second, till group, with lower conductivities, are located on the flanks of the valley. The thickness and complexity of sediments varied across the study area. To the E/SE of the valley, sediments are thick ( $40 \mathrm{~m})$, and more complex., In contrast the S/W/NW of the area, sediments are thinner $(\sim 10 \mathrm{~m})$ and more simple. Groundwater is found to flow towards the centre of the valley and along its axis, where a bedrock controlled divide forms two groundwater basins. Based on the results of this research, it is suggested that any future expansion of the tailings facility should be restricted to the western and southern side of the valley, where waters are more manageable.
\end{abstract}

Keywords (GeoRef Thesaurus, AGI): sediments, stratigraphy, hydraulic conductivity, ground water-surface water interaction, environmental management, tailings, Weichselian, Lapland, Finland.

*Corresponding author e-mail: peter.howett@helsinki.fi

Editorial handling: Antti Ojala (antti.ojala@gtk.fi) 


\section{Introduction}

Mines, despite their relatively small size, can have a large impact on the surrounding environment (Salomons, 1995). One of the biggest sources of environmental contamination from metal mining is acid mine drainage (AMD), with the oxidation of metal sulphides, for instance chalcopyrite $\left(\mathrm{CuFeS}_{2}\right)$, and the release of sulphuric acid to the environment (Gray, 1997). Waters in mining environments derive from various sources. Some of them are contamimated with metals and chemicals, such as process waters and tailings leachate waters, while others are pure natural waters, such as aquifer sources connected to dewatering of the mine or surface runoff following precipitation (Younger \& Wolkersdorfer, 2004). A key target in the sustainable management of mine water is to keep contaminated waters separated from the natural ones. This involves diverting natural waters and isolating highly contaminated waters, such as those related to AMD.

As the flow of both surface and groundwater domains provides the main pathways of mine pollutants to the environment, it is essential that they, and the geological materials that control them, are well understood and modelled (Heikkinen et al., 2008). A 3D hydrostratigraphical model can be a powerful tool in identifying these surface water and groundwater bodies, their connectivity with one another and therefore potential contaminant pathways. It provides a simplified, digitised representation of the natural and complex geological and hydrological systems (Bear \& Cheng, 2010). Artimo et al. (2004), demonstrated the importance of $3 \mathrm{D}$ modeling in the understanding of these local groundwater and geological systems and how it can be used to manage and lower the impacts of mining activity.

Furthermore, with a demand to develop environmentally friendly, sustainable and socially acceptable mining practices (Wessman et al., 2014), and with an increase in metal ore exploration and extraction in Finland (Eilu, 2012), it is ever more vital to understand and control these environmental impacts imposed by mining activity. This study outlines the significance of constructing a representative geological model in the planning of a waste rock and processing facility at Rautuvaara, for the nearby Hannukainen (Iron Oxide Copper Gold) mine, Finnish Lapland (67³0'0"N, 235 $56^{\prime} 0^{\prime \prime}$ E, Fig1). According to existing plans, the facility, when extraction begins once more at Hannukainen, will include a processing plant and tailings management facility (TMF) in order to house an additional 76.3 Mt of tailings, of which 11.1 Mt will be of high sulphur grade with the potential to produce AMD (SRK, 2014).

Rautuvaara is a brown-field site, home to a historical processing plant and storing $7 \mathrm{Mt}$ of tailings from previous mining activity at Hannukainen, Saattopora and Rautuvaara (Fig.1C), making it an attractive potential locality for a new TMF (Räisänen et al., 2005). It lies within a formerly glaciated valley trending NE-SW covering an area approximately $4 \mathrm{~km}$ wide and $8 \mathrm{~km}$ long, acting as a natural valley landfill. Originally, the valley bottom was covered by peat and drained by a small brook, the Niesajoki, flowing south-westwards. However, due to previous mining operations the Niesajoki has been dammed, forming two man-made ponds used for the settling of mine tailings; man-made ditches divert much of the surface water through the valley, around the settling ponds (Närhi et al., 2012).

The area belongs to the ice-divide zone of the last glaciation, and is characterized by a low erosion rate and good preservation of earlier glacial and nonglacial sediments (Johansson \& Kujansuu 2005). It hosts a complex Quaternary stratigraphy, as shown in previous studies by Hirvas (1991) and Lunkka et al. (2014) at Rautuvaara, and Salonen et al. (2014) at Hannukainen. Also, because of the historic prospecting and mining at Rautuvaara, the bedrock composition is well known. It consists of Paleoproterozoic metamorphic rocks such as quartz monzonite, quartzite, diorite, skarn and amphibolite (Hiltunen, 1982). Hiltunen observed that faulting and bedrock fracturing within the Rautuvaara area has a common trend, NE-SW. This is parallel to the valley axis and may have an effect on the underlying hydrology. However, little is known about the complexity of the subsurface geology or the distribution and behaviour of local groundwaters, 

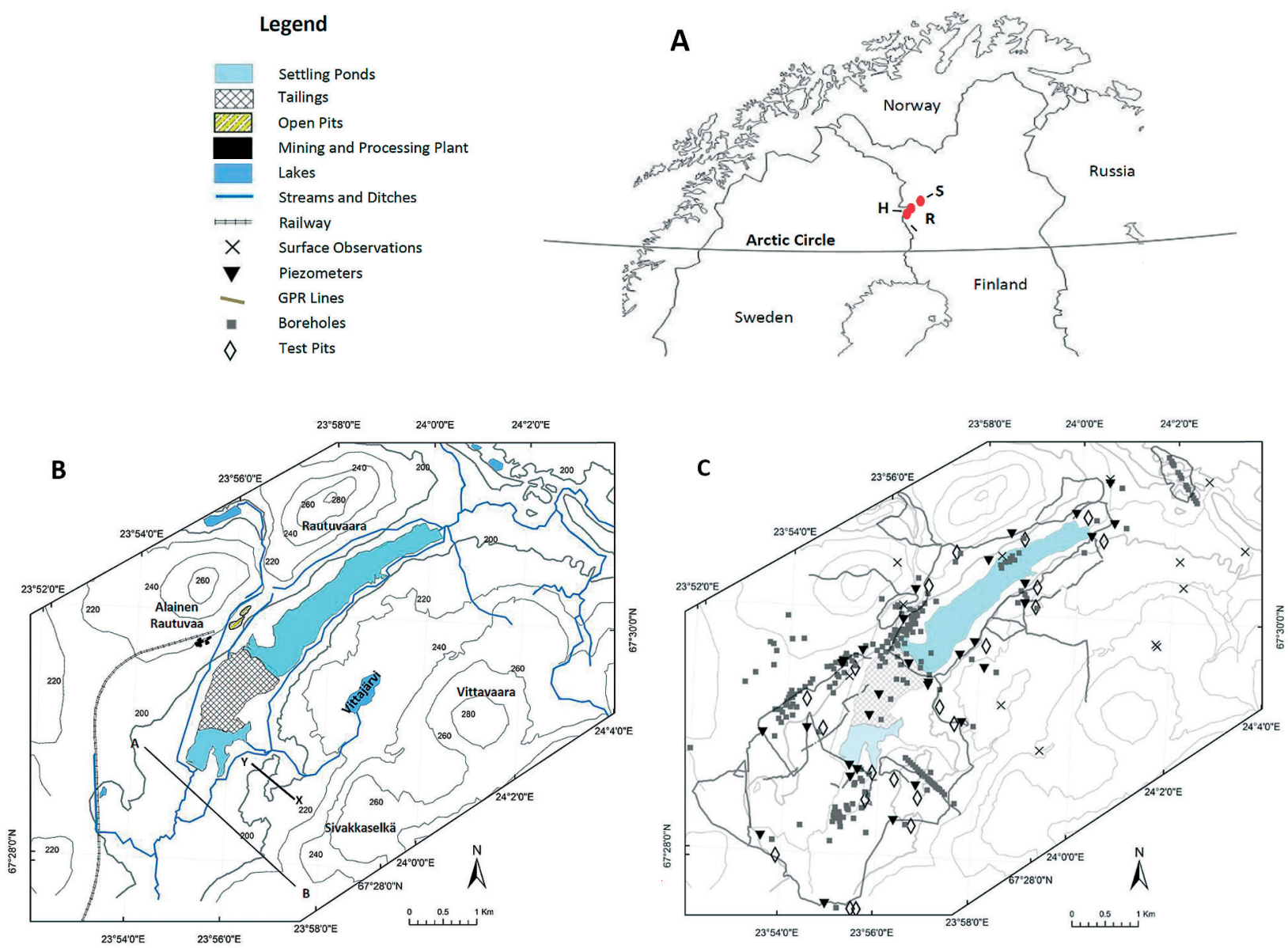

Fig. 1. A) Showing the location of the study site in relation to northern Europe. $\mathrm{R}=$ Rautuvaara; $\mathrm{H}=\mathrm{Hannukainen;} \mathrm{S}=$ Saattopora.

B) Map showing general topography and the main surface water features including man-made settling ponds and ditches. Existing mining waste dumps, open pit and processing facilities are located at Rautuvaara at the base of Alainen Rautuvaara. A-B is the location of cross section, Fig. 7. Line X-Y is the location of GPR line (Fig. 3).

C) Distribution of data sets i.e. boreholes, GPR lines, piezometers, springs and test pits. Boreholes are clustered around the old mining areas to the west of the study site.

therefore it is unclear how much influence bedrock fracturing has on the hydrology.

For the wastewaters to be monitored and controlled safely and acceptably, it is of crucial importance that the hydrogeological conditions are known. This study aims to increase this knowledge by examining the geological and hydrostratigraphical characteristics of the Niesajoki valley. It is assumed that this approach will, for its part, support the concept of environmentally acceptable mining (Thornton, 1996).

\section{Study Site}

Rautuvaara is situated within the municipality of Kolari in Finnish Lapland, approximately ten kilometres east of the Swedish border (Fig. 1A). The valley bottom is on average $190 \mathrm{~m}$ above sea level, with the surrounding hills of Rautuvaara and Alainen Rautuvaara to the NW and Vittavaara and Sivakkaselkä to the SE at approximately $280 \mathrm{~m}$ and $265 \mathrm{~m}, 285 \mathrm{~m}$ and $275 \mathrm{~m}$, respectively, above sea level (Fig. 1B). 
The vegetation consists of sparse coniferous forests of spruce, pine and also birch, with mosses, berries and shrubs growing throughout the forest floor. The climate is dry and mild in the summer and wet and cold in the winter, with local average annual precipitation at $528 \mathrm{~mm}$, half of which is snowfall. Snow depth is $70-80 \mathrm{~cm}$ per year, with coverage lasting for approximately 180 days. This combination of vegetation and climate is typical of a taiga (boreal) environment.

Land use is restricted, as the land is privately owned and largely run by Rautaruukki with on-site facilities existing for expansion, including transport links via rail, road and an $11 \mathrm{kV}$ power line. However, forests are actively maintained by the municipality, with clearance and reforestation occurring within the valley area. There is also a small waste water plant to the north of the larger settling pond. In the greater area, reindeer herding, tourism, and fishing for trout and salmon is common, which therefore demonstrates the fragility and susceptibility of the environment.

The surface water system is constrained naturally by the valley and also artificially by the dams to the north of the site, and to the south. Much of the surface waters that flow overland are collected in man-made ditches and diverted around the current tailings facility and into the Niesajoki brook further downstream.

The former Rautuvaara open pit (Fig. 1B) cuts through a 17-m-thick package of Quaternary sediments, which was earlier considered to be a representative section of Middle and Late Pleistocene strata in Lapland (Hirvas 1991). However, a recent study by Lunkka et al. (2014) has challenged this interpretation and has proposed that the Rautuvaara site comprises of sediments only from the Late Pleistocene, mostly representing glacial and non-glacial lacustrine sediments of Weichselian regional stage. This is supported by observations from the nearby Hannukainen locality, where Mid- and LateWeichselian sediments built up a sediment series with a considerable thickness of 20 30 metres (Salonen et al., 2014). However, it is also possible that pre-Weichselian sediments exist within the area, as demonstrated with the Sivakkapalo interglacial site (Hirvas, 1991; Johansson et al., 2005) about two kilometres south-east of Rautuvaara.

\section{Materials and Methods}

To construct the hydrostratigraphical model, several data sets were used to compile the $3 \mathrm{D}$ architecture of the valley. A LiDAR-based digital elevation model (DEM) was acquired from the Finnish National Land Survey, at a resolution of $2 \mathrm{~m}$. Using the spatial database software ArcGIS, the DEM was processed, creating separate overlaying rasters for slope and hill shade effects to enhance the topographical features (Fig. 2). The DEM was also used to extract altitude coordinates for the other various data sets, using the 'extract multiple values' tool, which allowed for both a greater 3D accuracy and compatibility between data.

Borehole data was acquired from previous prospecting studies (Mattila, 1976; Korvuo, 1981; SRK, 2014), yielding information on bedrock surface elevations and sediment types. A total

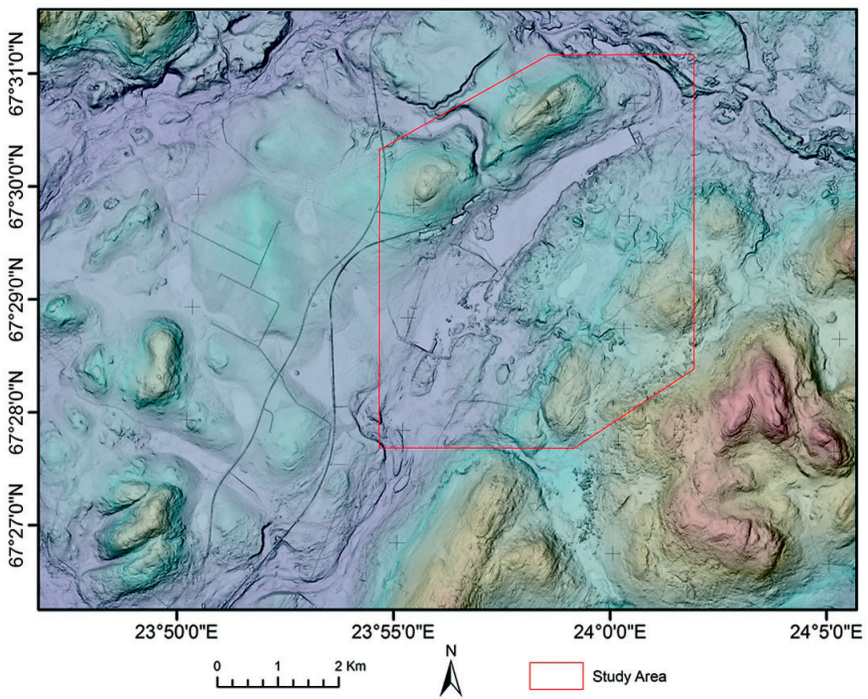

Fig. 2. Digital elevation model (DEM) showing the greater Rautuvaara area. The red box indicates the study site. The DEM was made using $2 \mathrm{~m}$ resolution LiDAR data with additional hill shade mapping and slope analysis in ArcGIS. With permission from the Geological Society of Finland. 
number of 240 boreholes were used. Altitudes for each borehole were extracted and assigned from the DEM raster using ArcGIS. The boreholes were also used to calculate an average electromagnetic wave velocity for overlying sediments $(0.0846 \mathrm{~m} / \mathrm{ns})$. This velocity was used in the processing of ground penetrating radar (GPR) survey data to convert two way time (TWT) to depth, as later discussed.

A piezometric surface was identified within the modelled area with the use of GPR analysis, surface water data and 34 groundwater monitoring wells (Fig. 1C). Seven of these wells were installed during the filling-in of test pits of this study, to a maximum depth of $6 \mathrm{~m}$. The others were set up by an environmental consulting company (SRK) and the Geological Survey of Finland (GTK) to an average depth of $20 \mathrm{~m}$. Measurements were collected on the same day during the summer. The groundwater localities and depths were stored as a series of xyz points within a txt file and interpolated, using an ordinary kriging algorithm in ArcGIS (with a spherical semi-variogram model and a variable search radius), from which flow directions could be ascertained. Hydraulic conductivities were, for all but two values, calculated from the grain size analysis of sediment samples collected from test pits using the Beyer equation (Rosas et al., 2013), with the remaining two values deriving from the Hvorslev slug test method (Fetter, 2001) from wells, carried out by SRK (2014).

To investigate the Quaternary sediments deposited upon the Precambrian bedrock a total number of 21 test pits (TP1-TP21) were excavated in and around the valley area (Fig 1C), to an average depth of $4 \mathrm{~m}$. Sediments and their lithofacies were described in detail, and a total of 37 sediment samples were taken in order to determine hydraulic conductivities. Clast orientation data was obtained from tills within several test pits to give an indication of palaeoglacial flow directions. This was done by using an average direction from 50 pebbles, with at least a 2:1 xy ratio. This was complimented with a number of borehole logs and GPR survey data.

Ten OSL samples were obtained by pounding a 4-cm-diametre copper tube into freshly cleaned sediment faces. Sorted sand or fine gravel deposits, representing presumably well-bleached littoral or fluvial environments were sampled, and the tubes were immediately sealed at both ends. Dose rate measurements for the OSL age determinations were measured on-site using a portable spectrometre equipped with a $\mathrm{NaI}$ scintillation detector. The dating was based on the SAR protocol, as described by Murray \& Wintle (2000) and was performed in the Laboratory of Chronology, University of Helsinki.

GPR surveys were carried out throughout an extensive area, at a total combined distance of 67 $\mathrm{km}$ (Figure 1C). A MALÅ GPR unit with two rough terrain antennas (RTA) were used for the data acquisition. A $50 \mathrm{MHz}$ RTA was initially in operation however, due to the local conditions, a $100 \mathrm{MHz}$ RTA was deemed more appropriate and was used for the majority of data acquisition. A time trigger was applied at an interval of 0.5 seconds, and a Garmin GPS was then integrated into the system to record the coordinates of the survey lines. The GPR data was processed using ReflexW software, following the processing flow as outlined below. The GPR file trace headers were modified to include both the altitudes extracted from the DEM and the xy coordinates, transformed from WGS84 to ETRS89 TM35FIN (the chosen coordinate system).

A series of processing steps were applied to the raw GPR data in order to clean, filter, and remove noise as well as correct for topography. The process flow 'remove start-time' was carried out on all lines manually in order to remove the first arrival airwave recorded by the receiver. The background removal stage subtracts an average trace from the whole profile, eliminating consistent perturbation and allowing one to see signals, previously covered by noise (Reynolds, 2011). Dynamic correction acts upon each independent trace using a predefined constant velocity $\left(0.0846 \mathrm{ums}^{-1}\right)$ and the distance between the source and receiver $(4.2 \mathrm{~m})$, to remove the effect of normal move-out (Kearey et al., 2002). A band-pass frequency filter was applied to each trace within the profile in order to eliminate and/or suppress amplitudes outside of the central frequency ranges and plateaus. Before the data was corrected 
for topography a manual (y) gain was used to emphasise amplitudes at depths where significant structural features were not clearly seen. Finally, a topographical migration and a 3D topographical correction were computed based on a constant velocity $\left(0.0846 \mathrm{ums}^{-1}\right)$ and altitude values that were extracted from the $2 \mathrm{~m}$ resolution DEM and assigned to the trace headers.

The GPR lines provided information for bedrock elevations, groundwater tables and, sedimentary properties such as structures and contacts, Fig. 3. This reinforces the borehole and test pit data. Along each surveyed line boundaries/ surfaces were traced and 'picked' in ReflexW. These 'picks' were in the format of xyz data and could therefore be combined with data from boreholes/ piezometres/test pits and stored as .txt files (in xyz format). This xyz data was then imported into ArcGIS. Corresponding surfaces e.g. bedrock surface elevation could then be interpolated using kriging and the inverse distance weighting interpolation tools.

The sediment thickness was calculated using a lower resolution DEM of $10 \mathrm{~m}$ (Fig. 4A) and the interpolated bedrock elevation model from borehole, GPR and test pit data (Fig. 4B). Using ArcGIS these surfaces were subtracted from one another to produce the sediment thickness map (Fig. 4C).

\section{Results}

\subsection{Bedrock surface and sediment thickness}

Interpolations based on the observations of the bedrock surface, produced a bedrock DEM (Fig. 4B). The model illustrates that the bedrock elevation varies between 170-260 m.a.s.l, and that the surface topography is bounded by the bedrock topography. Nevertheless, to the northern end of the larger settling pond, the bedrock valley is steeper and narrower, due to a saddle-shaped rise in the bedrock, observed on the eastern side of the valley. This is less so in the south where the bedrock is generally lower (170 m.a.s.l.) and the valley widens into a small basin-like depression. At the southernmost area, where the Niesajoki brook flows out from the valley basin, the bedrock is relatively close to the ground surface, as observed in TP9 and TP15 where it is at $3.5 \mathrm{~m}$ and $2.5 \mathrm{~m}$ depth, respectively. The bedrock itself appears to be block-weathered and there are no indications of glacially striated surfaces. The block-weathering has potential to increase the hydraulic conductivities and therefore groundwater velocity as groundwater will exploit the discontinuities between the weathered bedrock blocks.

Fig. 4C indicates the thickness of sediments
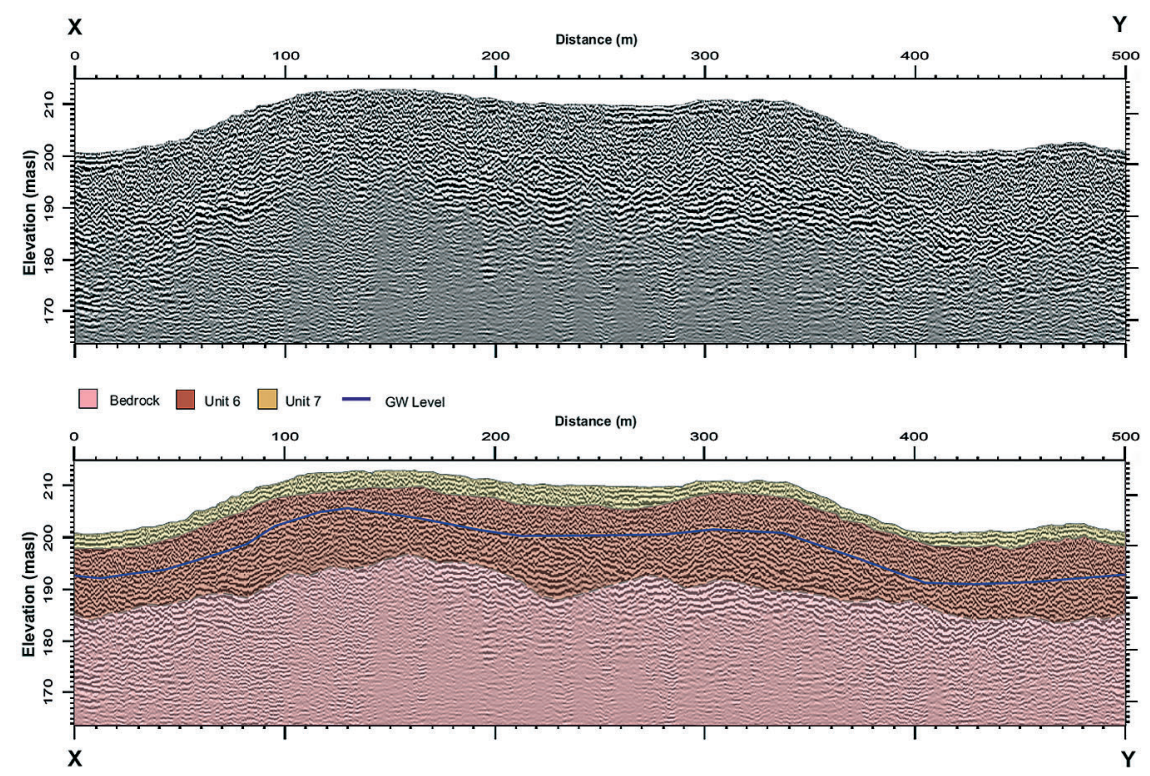

Fig. 3. GPR profile taken from the SE area of the site (see Fig. 1B). Top profile is without interpretation and shows the profile after processing. Lower profile shows the 'picked' surfaces between different sedimentary packages, bedrock and GW observations. Unit numbers have also been assigned to the two identified sediment layers, Unit 6 and Unit 7. 

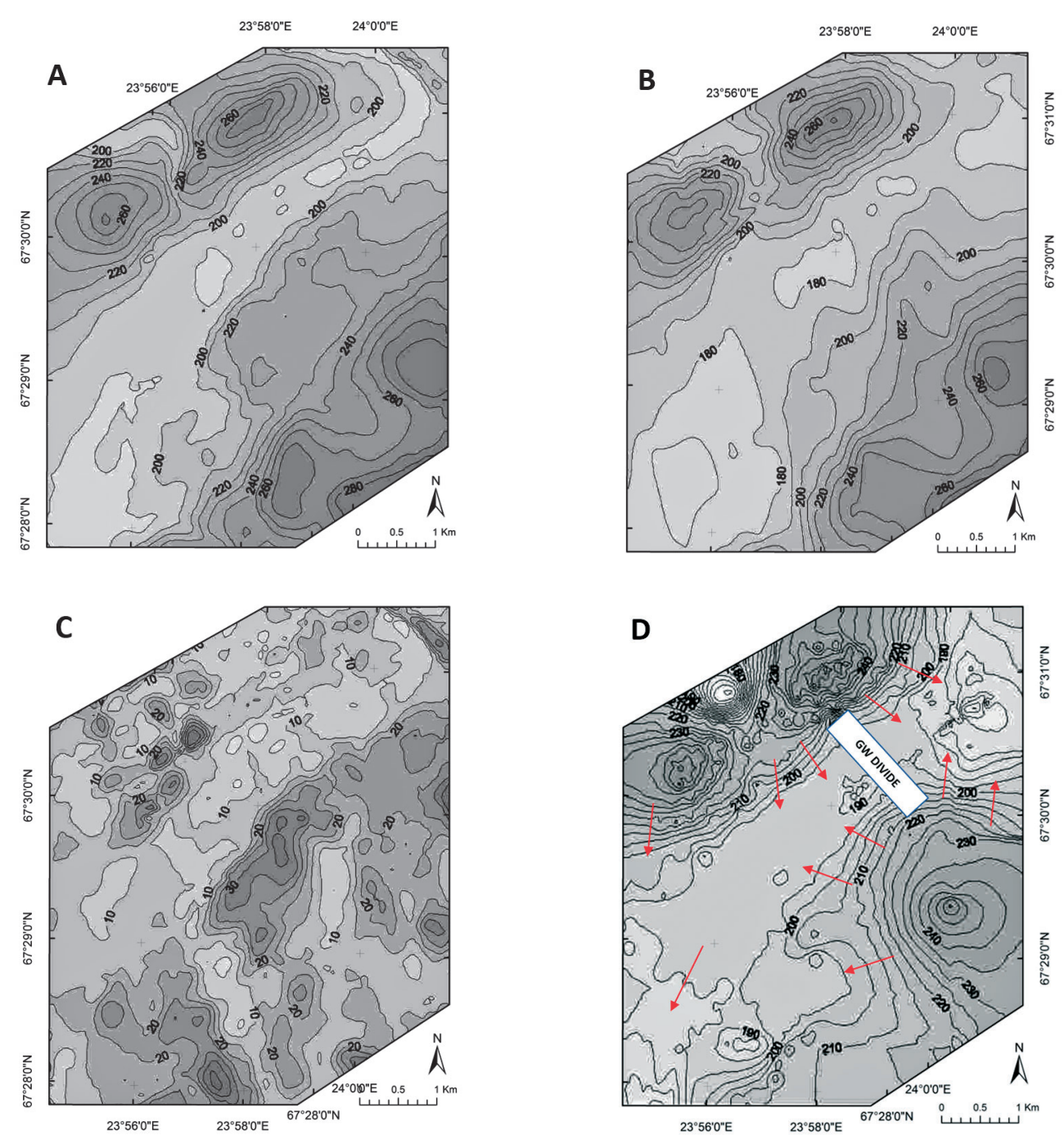

Fig. 4. A) Showing a contoured DEM at a $10 \mathrm{~m}$ resolution. Used to calculate sediment thicknesses (with permission of the Finnish National Land Survey). B) Bedrock topography based on borehole and GPR data, interpolated using inversedistance weighting (IDW). C) Sedimentary thickness map calculated in Surfer using raster math tools, extracting the bedrock elevation surface from the DEM surface. D) IDW pieziometric surface, using data from wells, surface discharge sites and GPR data. Arrows indicate main groundwater flow directions. Groundwater divide is shown by the rectangle.

within the valley basin. Sediments within the valley are relatively thick, with an average of $19 \mathrm{~m}$. Fig. $4 \mathrm{C}$ is calculated as the difference between the DEM and the bedrock elevation (Fig. 4A and Fig. 4B respectively). Access to sediments along the valley bottom is restricted, due to the ponds and tailings that fill a large part of the area. Nonetheless, based on modelled data, it is estimated that the sediment thickness along the bottom of the valley is between 10 and 15 metres. The thinnest deposits $(0-10 \mathrm{~m})$ are located on the NW side of the valley. Bedrock was observed at $4 \mathrm{~m}$ depth in TP4 (Fig. 4B and 6), and outcrops on the upper flanks of the Rautuvaara hill.

There are a number of areas where the sediment thickness is greater than $19 \mathrm{~m}$. One of those areas is 
around the Rautuvaara open pit, where a thick sediment package of approximately $22 \mathrm{~m}$ overlays the bedrock (Hirvas, 1991). In the small valley to the north of the open pits, between the hills of Rautuvaara and Alainen, contains sediments with a thickness of $20-30 \mathrm{~m}$. This is indicated in the GPR survey data. The southern basin-area and the eastern hummocky-area have a thick sediment cover ranging between 20-40 m. Large areas of the valley bottom are covered in peat, with an average thickness of 2 $\mathrm{m}$. This is also indicated by GPR survey data.

\subsection{Sediments and their age}

The sedimentary succession at Rautuvaara is complex, containing a variety of late Quaternary deposits that represent glacial and ice-free events. Based on sedimentary sections, test pits observations, previously published borehole data (Kuorvuo, 1982; SRK, 2014) and OSL age determinations a composite sediment log can be established for the study area (Fig. 5).
Based on sedimentary observations and OSL ages eight separate stratigraphical units have been identified within the Niesajoki valley. These eight units, their occurrence and their stratigraphical relationships, can be visualised on the composite map (Fig. 6) Borehole data (e.g. RAU12, HYD09, RAU12, HYD21, HYD 20, HYD19) indicates that sub-till sands and gravels occasionally occur beneath these eight units. This is especially so in the SE where sediments can be $40 \mathrm{~m}$ thick (Fig. 7). Silt layers were also observed in borehole records. There is not enough information to correlate or explain the sedimentary history of these sub-till units. The composite log (Fig. 5), is a representation of these combined observations based upon the central area of the Niesajoki valley, where the average thickness of sediments is 19 metres. This is demonstrated in Fig. 7 , where a cross-section through the SE of the valley is presented.

The lowermost sedimentary unit exposed in test pits is a dark grey, silty to sandy, matrix-supported diamicton (Unit 1; Fig. 5). It was identified in two test pits (TP17, TP18; Fig. 6) on the eastern side

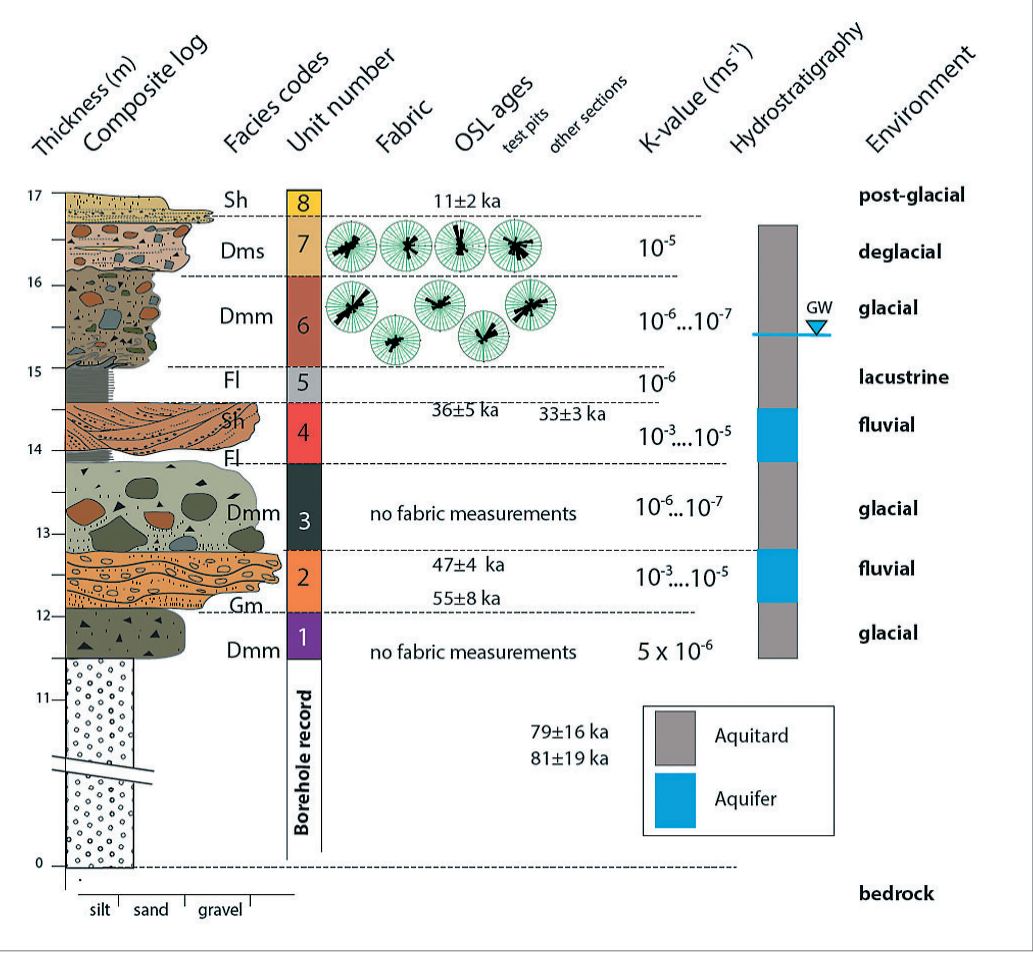

Fig. 5. Composite log showing the stratigraphical sequence of the eight identified units within the study area based on OSL dates, lithofacies characteristics and fabrics. Hydraulic conductivity values/ranges are given where appropriate along with their hydrostratigraphical interpretations as well as an environmental depositional environment. Unit numbers/colours correlate with subsequent figures. Facies code system follows Eyles et al. (1983). 


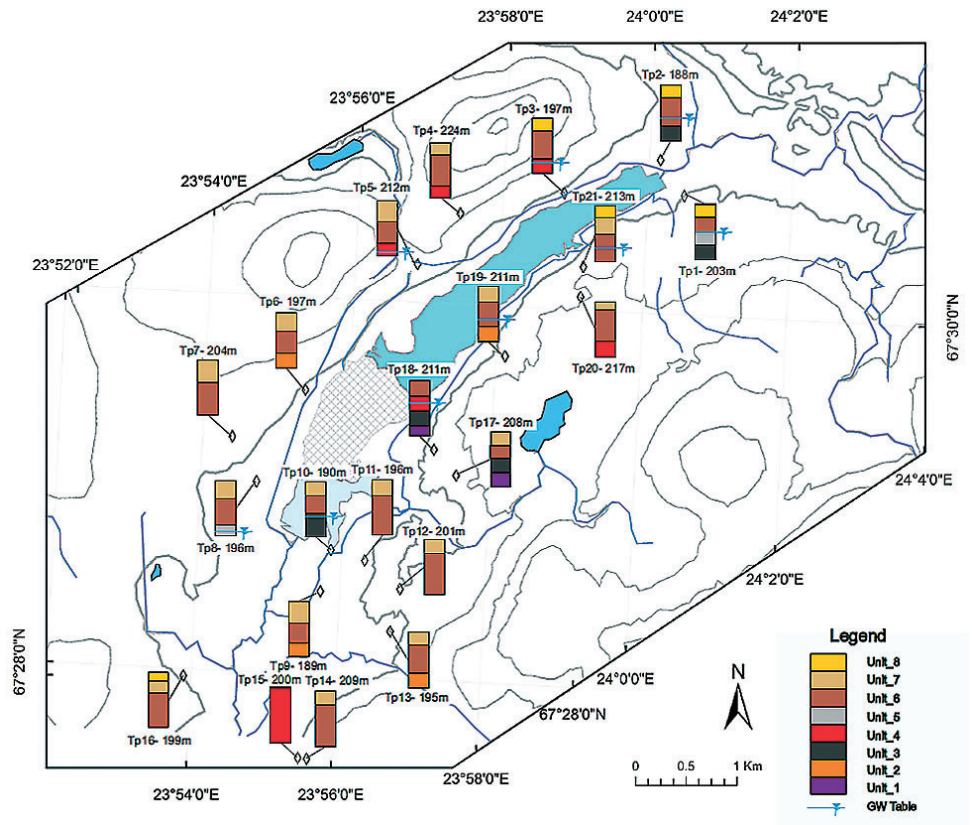

Fig. 6. Composite map showing the distribution and relationships of the eight units based on test pit observations and interpretations. The values indicated next to the test pit names refer to the ground surface elevation (m a.s.l) for each test pit locality. Groundwater levels are indicated where recorded and in which unit they occur in. Logs are not to scale. of the study area. Based on its compactness and massive structure, it was interpreted as basal till. No clastic fabric measurements were carried out, however one hydraulic conductivity value was calculated from TP17. This gave a value of $10^{-6} \mathrm{~ms}^{-1}$.

Unit 2 consists of very coarsegrained sands and bouldery gravels that are iron-stained and horizontally stratified. There are also indications of post-depositional shearing and compacting from glacial activity. These coarse-grained sands and gravels were probably deposited in a high-energy, fluvial or glacio-fluvial environment. This unit was encountered in several test pits (TP6, 9, 13 and 19) throughout the valley centre, where it is exposed at places (Fig. 6). Unit 2 occurs beneath Unit 6 at every locality. It is in contact with bedrock at one locality. This

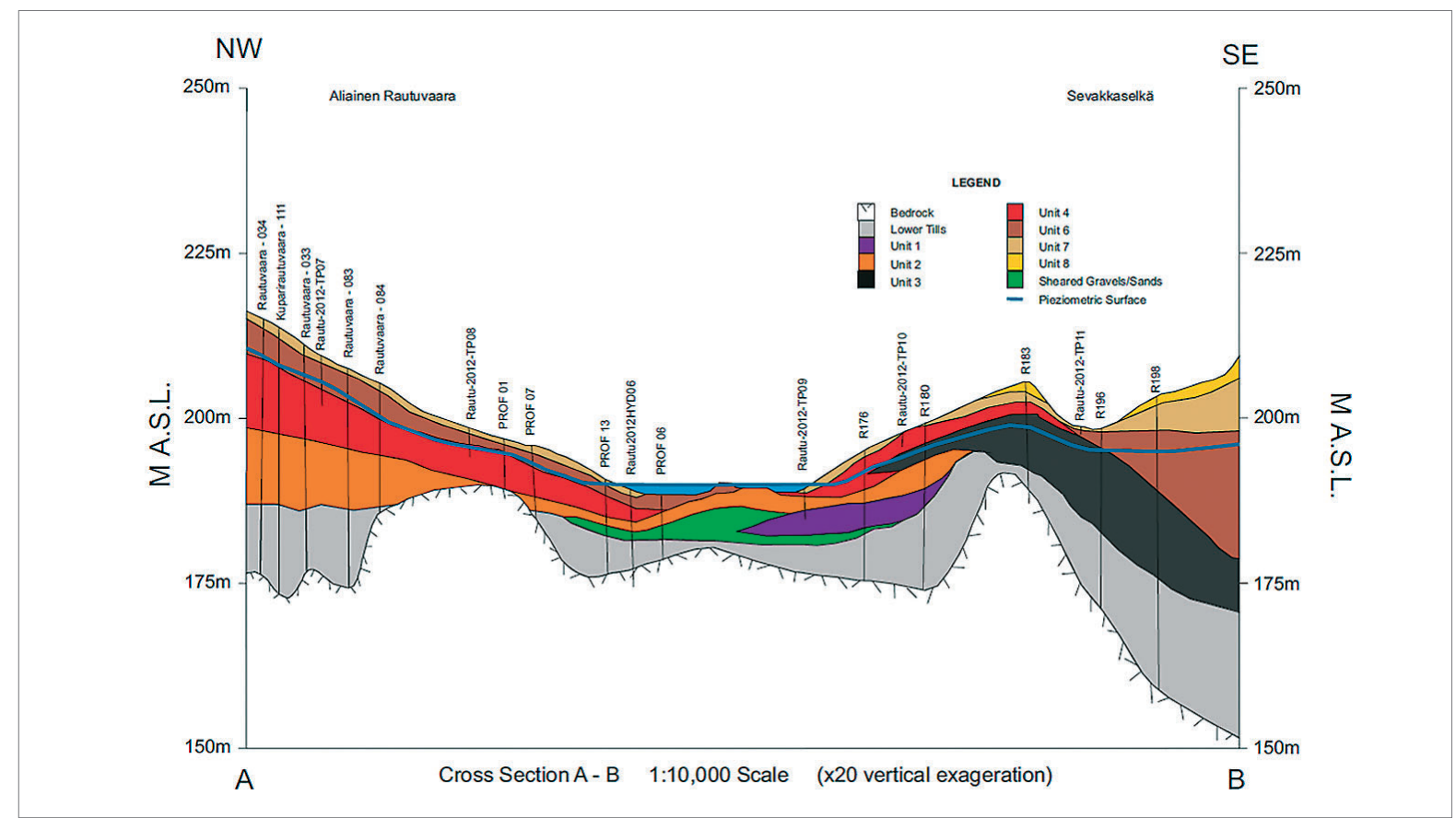

Fig. 7. Cross-Section, A-B, of the south-eastern area cutting through the southern settling pond, as indicated in Fig. 1. B. Boundaries are inferred from various test pit, borehole and GPR data. The piezometric surface is based on groundwater observations from wells and test pits. 
absence of a lower contact makes calculating its thickness difficult. Two OSL-ages were determined from Unit $2(55 \pm 8 \mathrm{ka}$ and $47 \pm 4 \mathrm{ka})$ indicating that they are of Mid-Weichselian age. The hydraulic conductivity values inferred from grain size distribution vary between $10^{-3}$ and $10^{-5} \mathrm{~ms}^{-1}$.

Unit 3 is a massive silty diamicton, observed in three test pits (TP10, 17 and 18) at the southern end of the valley, and in two test pits (TP1 and TP2) in the north. Unit 3 is interpreted as till due to its massive, unsorted texture. It overlies Unit 1 and underlies Units 6, 5 and 4 (Fig. 6), with an average thickness of $1 \mathrm{~m}$. Hydraulic conductivity values for this till range between $10^{-6}$ and $10^{-7} \mathrm{~ms}^{-1}$.

Unit 4 comprises of sub-horizontal/planar crossbedded sands and gravels that are interpreted to be deposited by flowing water. Unit 4 is extensive, occurring in TP3, 4, 5, 15, 18, 20 and its thickness varies between $0.2 \mathrm{~m}-2.5 \mathrm{~m}$. In TP15 it is in contact with the bedrock, elsewhere it underlies Unit 6 and in TP18 lies on top of Unit 3 (Fig. 6). The OSL sample from this unit give an age of $36 \pm 5 \mathrm{ka}$. This date is supported by a correlative stratified sand unit located at Paloselkä, two kilometres south of study area border. These sands have an age of $33 \pm 7 \mathrm{ka}$ (Table 1). Unit 4 has a range of hydraulic conductivity values from $10^{-3}-10^{-5} \mathrm{~ms}^{-1}$.

Unit 5, found in TP1 and 8 (Fig. 6), is composed of laminated silt and sand deposited in a relatively low energy environment indicating rhythmic changes in current velocities. It is most likely that Unit 5 is of glaciolacustrine origin. This unit is relatively thin $(-0.5 \mathrm{~m})$. It underlies Unit 6 .
One conductivity value was calculated for this unit with a value of $10^{-6} \mathrm{~ms}^{-1}$.

Unit 6 is a massive, sandy diamicton with an erosional lower contact. This unit is the most extensive unit in the area, found in all but one test pit (Fig. 6), with an average thickness of $3 \mathrm{~m}$. Clasts indicate a preferred fabric from SW to NE. Based on the nature of its lower contact, variable lithology, poorly-sorted grain-size distribution and angularity of the clasts, Unit 6 is a basal lodgement till. Calculated hydraulic conductivity for Unit 6 have values ranging between $10^{-6}-10^{-7} \mathrm{~ms}^{-1}$.

Unit 7 is a loose, often brownish, sandy diamicton with a poorly developed fabric. It has a gradational lower contact, which in places is stratified and contains sandy lenses. Based on the gradational contact, stratification, partial sorting and relatively loose packing, Unit 7 can be interpreted as a melt-out till. It occurs as the topmost unit throughout the southern and central parts of the study area. The average thickness is $0.5 \mathrm{~m}$ however, in Unit 6 it is $2 \mathrm{~m}$ thick. It overlies Unit 6 and has calculated conductivity values averaging at $10^{-5}$ $\mathrm{ms}^{-1}$.

Unit 8 comprises of sub-horizontally layered/ planar cross-bedded coarse-medium sands and gravels. It is only found in four test pits (TP1, 2, 3 and 21; Fig. 6) to the north of the area, where the unit is ca. $1 \mathrm{~m}$. Stratified sands examined in test pit 21 , close to the valley centre, yield an age of $11 \pm 2$ $\mathrm{ka}$. The sands of Unit 8 were interpreted as outwash/ river terrace deposits related to Late Weichselian/ Holocene deglaciation.

Table 1. OSL samples and the units they represent

\begin{tabular}{|c|c|c|c|c|c|}
\hline Sample ID & OSL-ID & Lithology & $\begin{array}{l}\text { Sedimentary } \\
\text { environment }\end{array}$ & $\begin{array}{l}\text { Eq-dose } \\
\text { (mGy) }\end{array}$ & Age \\
\hline TP3, unit 4 & Hel-TL04268 & massive silty sand & outwash or river terrace (Unit 4) & 135000 & $36 \pm 5$ \\
\hline TP6, unit 3 & Hel-TL04269 & stratified sand and gravel & fluvial or glaciofluvial (Unit 2) & 170200 & $55 \pm 8$ \\
\hline TPI8, unit 3 & Hel-TL04270 & laminated sand & fluvial or glaciofluvial (Unit 4) & 54400 & $20 \pm 4$ \\
\hline TPI9, unit 3 & Hel-TL0427I & stratified sand, gravel & fluvial or glaciofluvial (Unit 2) & 122300 & $47 \pm 7$ \\
\hline TP2I, unit 2 & Hel-TL04273 & stratified sand, gravel & littoral sand (Unit 8) & 31500 & $11 \pm 2$ \\
\hline Sadinkangas & Hel-TL04266 & cross-bedded sand & high-energy: outwash or river terrace (Unit 4) & 87600 & $81 \pm 19$ \\
\hline Aavahelukka & Hel-TL04265 & cross-bedded sand & high-energy: outwash or river terrace (Unit 4) & 114000 & $79 \pm 16$ \\
\hline Paloselkä & Hel-TL04267 & stratified sand & littoral or river terrace & 41532 & $33 \pm 7$ \\
\hline
\end{tabular}


The topmost fine-medium grained sands, found exposed extensively at the ground surface are commonly massive, usually with soils on top. The thickest sands were at the northern end of the study area. These sands represent littoral or aeolian deposits.

Three additional sites were examined close to the field area. At each site OSL ages were determined. The first of these sites is a sand pit located at Aavahelukka, situated approximately 10 $\mathrm{km}$ north of Rautuvaara. Here a 2.1 metre-thick section was logged. At the top of the section a 0.6metre thick, crudely bedded and massive sand unit was logged which overlay a $1.5 \mathrm{~m}$ bed of crossbedded sand. An age of $79 \pm 16$ ka was obtained from these underlying sands. The second site at Sadinkangas is approximately $5 \mathrm{~km}$ southwest from Rautuvaara. Here a 2.1-metre-thick section consisting of trough-cross bedded sands were dated using OSL at $81 \pm 19 \mathrm{ka}$. The third site, at Paloselkä hill, is in the immediate vicinity of the study area to the SW. Here, a shallow trench dug into ground, exposed a diamicton capped with a 0.2 metre-thick unit that consists of laminated silts and sands. On top of which is a 1.2 metre-thick sand unit displaying sub-horizontal bedding with an ice-wedge cast structure. This sand unit has been dated at $33 \pm 7$ ka (Table 1).

OSL-age determinations, acquired from five test pits and three sections, yield ages from 81000 years to 11000 years (Table 1). They form four distinct groups: the oldest ages being 81000 to 79000 years the second 47000 to 55000 ; the third 33000 to 36000 and; the youngest age is 11000 years. The youngest three age groups represent Units 2, 4 and 8 described from the test pits, respectively. One dating result, Hel-TL04270, gave an age of $20 \pm 4$ ka, which cannot be related to other ages.

The two oldest dates obtained from the Aavahelukka section and from the Sadinkangas sand pit indicate that these fluvial sediments date back to the Early Weichselian ice free phase. These units may also be present in the borehole records obtained here (Fig. 5), which is supported by the sedimentary record obtained from the Rautuvaara open pit section (Lunkka et al., 2014).

\subsection{Surface water/ Groundwater flow}

As indicated from the piezometric surface map (Fig. 4D), it is evident that there is a preferential groundwater flow towards the valley bottom and then along the valley's axis. The flow seems to divide towards the northern end of the valley. Flows to the north of the divide flow toward the NE and waters south of the divide towards the SW. The groundwater divide seems to be a major boundary within the hydrogeological system. Waters north of the divide are currently outside the affected zone of the tailings, which limits the area of investigation to south of the groundwater divide. The only groundwater leaving the area therefore is that which flows out through the SW of the area. Groundwater can be observed discharging as springs in the low wetland areas in the valley bottom.

The groundwater table is observed most frequently at its highest in Unit 6, although it also occurs in Units 3, 4 and 5. Therefore, Units 7 and 8 constitute the unsaturated zone. The main aquifers are Units 2 and 4, with conductivity values of $10^{-(3-5)} \mathrm{ms}^{-1}$. Although the till Units 1,3 and 5 have relatively low hydraulic conductivities $\left(-10^{-(5-6)}\right.$ $\left.\mathrm{ms}^{-1}\right)$, they are still relatively good aquifers, with only Unit 5 having a poor conductive value $\left(10^{-7} \mathrm{~ms}^{-1}\right)$.

\section{Discussion}

Based on the results presented here, previous publications from the Rautuvaara (Hirvas, 1991; Lunkka et al., 2014) and Hannukainen areas (Salonen et al., 2014), and percussion drillings related to mining activities in the area (Korvuo, 1981), it is possible to divide the examined strata into three main sedimentary successions each of which representing a glacial/ice-free cycle.

The lowermost stratigraphical succession I consists of Mid-Weichselian sediments. Till Unit 1 can be related to the first Mid-Weichselian glaciation (Johansson et al., 2011), which is overlain by thick, inter-glacial Mid-Weichselian fluvial sands, Unit 2 (Lunkka et al., 2014, Salonen et al., 2014) (Fig. 8). The lower dark grey till (Unit 1) was only 


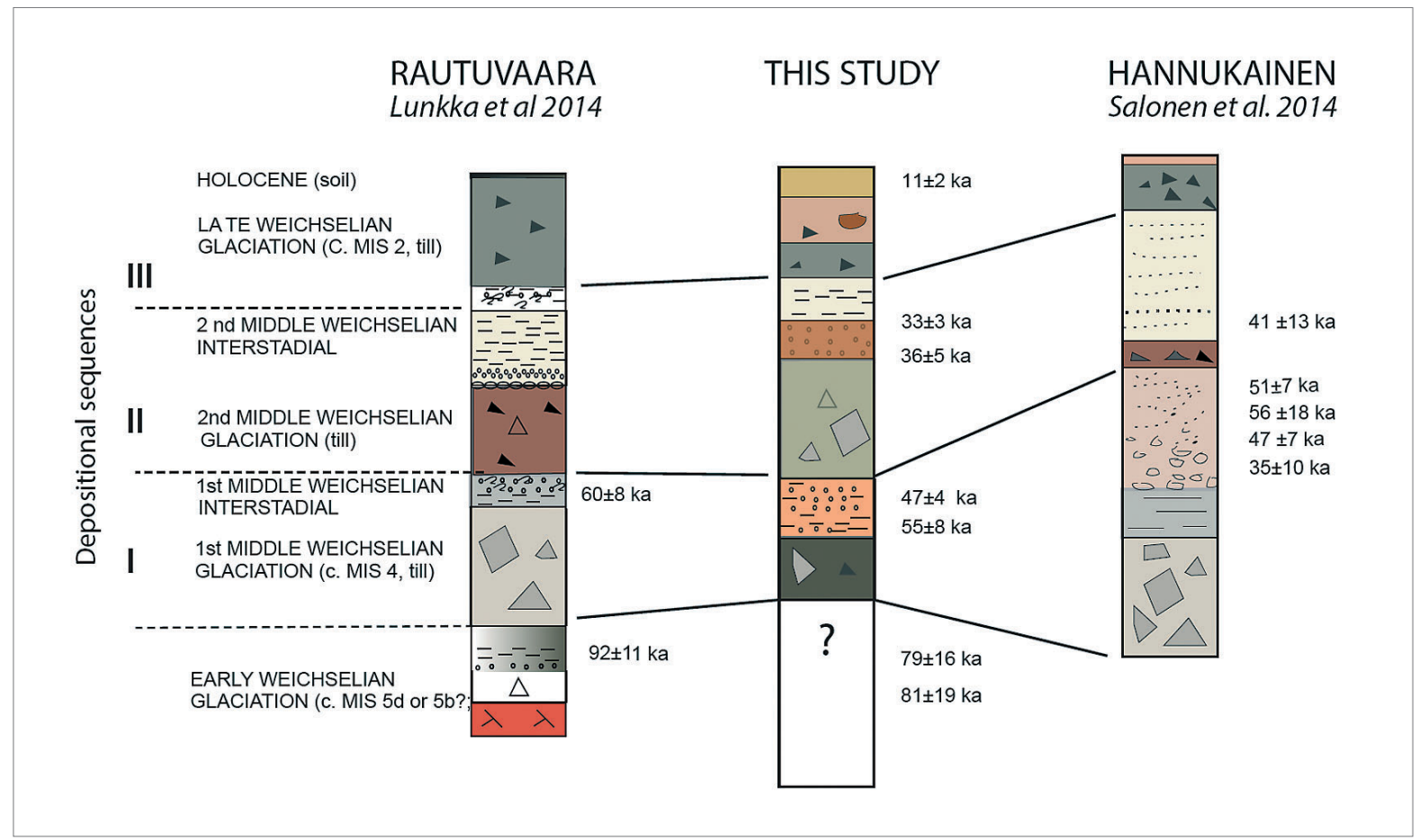

Fig. 8. Correlation diagram of stratigraphical sequences from Lunkka et al. (2014), Salonen et al. (2014), and this study, highlighting the three depositional sequences of Middle to Late Weichselian glacial/interglacial cycles.

encountered at the bottom of two test pits (TP17, TP18), and no detailed measurements were made about this till unit.

Stratigraphical succession II represents the second Mid-Weichselian glacial event (Unit 3, till). This event was followed by a second MidWeichselian ice-free period (Johansson et al. 2011) with meltwater, fluvial activity (sands and gravels in Unit 4) and lacustrine conditions (Unit 5) dating back to around $36 \mathrm{ka}$. Thick Mid-Weichselian sand and gravel deposits are also reported from Hannukainen (Salonen et al., 2014), where they have been interpreted as delta foreset sediments, 35 to $39 \mathrm{ka}$ old. Delta/outwash deposits in Sadinkangas and Aavahelukka are also of this age, and it is possible that the coarse-grained bar-like deposits in the centre of Niesajoki valley (TP15) are related to that icefree phase.

Stratigraphical succession III represents the Late Weichselian glacial advance (Unit 6, lodgement till), followed by deglaciation (Unit 7, melt-out till) and the occurrence of a post-glacial shoreline, with fluvial and aeolian processes within the area (Unit 8, sands and upper sands).

\subsection{Groundwater storages, flow and discharge}

These three stratigraphic successions described above can be further subdivided based on their hydraulic properties. Based on sedimentology and hydraulic conductivities two groups of hydrostratigraphical units can be identified within the valley. These are: 1) fluvial sediments, found along the central axis of the valley (Units 2 and 4), comprising largely of sands, gravels and some fines that have been compacted and sheared by the overlying ice, and; 2) tills, consisting of a mixture of clays and silts with various proportions of sand and gravel (Units 1, 3, 5 and 6), which dominate the flanks of the valley.

Hydraulic conductivity values for the fluvial sediments range from $10^{-3} \mathrm{~ms}^{-1}$ to $10^{-5} \mathrm{~ms}^{-1}$, which is common for these types of sediments (Freeze and 
Cherry, 1979; Bersezio et al., 1999). Secondary permeability caused by shearing, could further increase the conductivity of the units although, the extent of shearing is unknown. These fluvial sediments constitute the main aquifers within the valley.

The tills, although differing in grain-size and composition, yield similar hydraulic conductivity values of $10^{-5} \mathrm{~ms}^{-1}$ to $10^{-7} \mathrm{~ms}^{-1}$. These conductivity values are typical of till deposits (Heikkinen et al., 2002; Hinton et al., 1993; Anderson, 1989). Stephenson et al. (1988), accounts the variability in hydraulic conductivities of till to the amount of silt/clay that it contains. Unit 6 is one such compacted till unit that contains poorly sorted material generating low hydraulic conductivity values typical for tills, ranging between $10^{-6} \mathrm{~ms}^{-1}$ and $10^{-7} \mathrm{~ms}^{-1}$. Therefore Unit 6 can be considered as an aquiclude.

Silt layers deposited in glaciolacustrine settings occur occasionally between tills, as observed for example by Lunkka et al. (2014). However, they only occur in two test pits (TP1 and TP8). This implies that silt and clay layers are not forming extensive and continuous beds in the study area, although this may be due to the reworking of sediments by fluvial activity. No hydraulic conductivity values were calculated from the silt and clay layers, although silts typically demonstrate low hydraulic conductivity values, $10^{-7} \mathrm{~ms}^{-1}$ or less (Younger, 2007). The significance of this is that there may be perched/confined waters adding to the overall complexity of the architecture and groundwater flows.

Perched waters, caused by these low conductive silts, coud account for the extensive wetlands in the valley, especially in the valley centre and around Lake Vittajärvi, as peatland tends to form in areas where groundwater tables are naturally high or where there is a shallow confinement of waters close to the surface (Winter, 1988). These are areas which are susceptible to groundwater discharge.

As can be seen from Fig. 4D it is clear that the groundwater flow is towards the valley centre and along its axis, where it is spilt towards the northern area of the larger tailings pond by a groundwater divide. The bedrock topography for the area (Fig. $4 \mathrm{~B}$ ) suggests that the divide is produced by a saddleshaped elevated bedrock-high that separates the valley into two basins.

\subsection{Implications on Management of Tailings}

It has been demonstrated that the NW and southern parts of the valley are much simpler in terms of stratigraphy and hydraulic properties, than the opposite side of the valley to the NE/SE. Sediments in the NW and southern side of the valley are generally thinner $(0-15 \mathrm{~m})$ and tend to be more homogenous and isotropic. Fig. 6 shows that in the NW/S glacial fluvial deposits rest on top of the bedrock and are overlain by a till (Unit 6). In contrast, the NE/SE side of the valley comprises of thicker sediments $(10-40 \mathrm{~m})$ that consist of more than one succession of glacial fluvial sediments and tills (Fig. 6). The topographic morphology in the NE/SE of the area is hummocky; a feature related to melt-out tills. Melt-out tills are generally more heterogeneous and anisotropic in nature, and could account for the higher complexity of geology in this area (Anderson, 1989).

The contrast in complexities from one side of the valley to the other has a significant effect on the hydrogeology. A simpler, thinner succession of sediments will allow for easier management of waste water as it is easier to measure and model waters and deduce their potential pathways within the hydrological system. This will in effect lower the environmental impact that the facility has on the surrounding environment. In a more complex succession of sediments hydrological systems will naturally become less predictable and more difficult to model. Therefore management of local waters will equally become more difficult. On this basis it can be recommended that the NW/S area would be more optimal for the siting of the TMF (Fig 9). This is especially so for the high-sulphate, AMD producing wastes. A former proposal for the tailings management facility is also included in Fig. 9 (SRK, 2014). The main difference between the two proposals is the size of the proposed area and the 


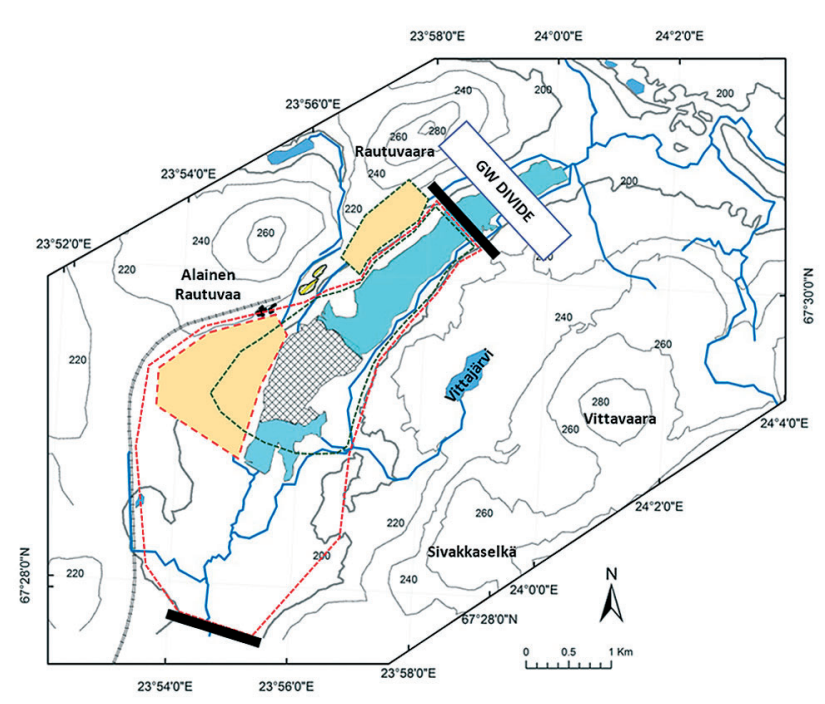

Fig. 9. Proposed tailings summary map, comparing the original SRK (2014) proposal for planned tailings (green dashed line), with those of this study, (red dashed line). The black boxes indicate dams. Faded yellow areas are the areas recommended for high-sulphide AMD producing tailings.

location of the AMD-producing wastes. This study allows for a larger area for the tailings to the NW and $S$. This is once again linked to the simplicity of the underlying sediments as mentioned above. The AMD waters would be better suited towards the SW end of the valley as the ground water divide is too close to the previously proposed locality in the $\mathrm{N}$ of the site (Fig. 9).

It can be presumed that the lining structures will leak (Alberta EPA, 1996), therefore storages should be located in a way that contaminated seepage waters can be collected effectively and treated. The optimal place for the southern dam therefore, should be within the narrow passage at the southern end of the valley, which serves as a funnel for collecting all surface water and, possible contaminated groundwater, within a single focal area. This allows clean water to be effectively separated from the mine impacted water and permits the treating and managing of the mine waters in optimal way.

Based on the detailed geological modelling, incorporating extensive GPR data, boreholes, piezometers, test pits, OSL samples and observations the main conclusions of the research are as follows:

The glacial sediments that compose parts of the Niesajoki river valley are relatively thick (ca. 40 $\mathrm{m})$ and are complex in their nature.

The OSL datings from sediments show three distinct groups that represent separate cycles of glacial/interglacial periods, all of Mid-Late Weichselian age.

The hydrostratigraphy, despite the complex geology, is relatively simple. Tills and fluvial sediments comprise the main hydrostratigraphical units in the valley, with the fluvial aquifers deposited along the valley axis, surrounded by the low conductive tills on the flanks of the valley.

Based on geological observations, groundwater flow and the interactions of local waters, this study concludes that the most suitable locations within the Niesajoki valley for the development of a tailings facility would be those areas to the south and NW of the valley. Here sediments are much more simple and thinner $(\mathrm{ca} .10 \mathrm{~m})$.

\section{Acknowledgements}

We would like to thank Talvikki Savolainen for her contribution and field assistance; Anu Kaakinen for her feedback and guidance; Northland Mining Finland $\mathrm{Oy}$ for their support and cooperation; and to the National Graduate School of Geology for the funding of the study. We would also like to take the opportunity to thank both Dr. Antti Pasanen and Prof. Juha-Pekka Lunkka for their constructive feedback, criticism and reviewing of the manuscript.

\section{References}

Alberta EPA, 1996. Action leakage rate guideline. Prepared by: Industrial waste and wastewater branch air and water approvals division. Alberta environmental protection agency. 8 p. Web address: http://environment.gov.ab.ca/ info/library/8818.pdf. 
Anderson, M.P. 1989. Hydrogeologic facies models to delineate large-scale spatial trends in glacial and glacial-fluvial sediments. Geological Society of America Bulletin 101, 501-511. http://dx.doi.org/10.1130/0016-7606(1989) 101\%3C0501:HFMTDL\%3E2.3.CO;2.

Artimo, A., Salonen, V.-P., Pietila, S. \& Parapera, S. 2004. Three-dimensional geologic modeling and groundwater flow modeling of the Töllinperä aquifer in the Hitura nickel mine area, Finland - providing the framework for restoration and protection of the aquifer. Bulletin of the Geological Survey of Finland 76, 5-17.

Bear, J. \& Cheng, A.H. 2010. Modelling groundwater flow and contaminant transport. Springer, London. 834 p.

Bersezio, R., Bini, A. \& Giudici, M. 1999. Effects of sediment heterogeneity on groundwater flow in a quaternary proglacial delta environment: joining facies analysis and numerical modelling. Sedimentary Geology 129, 327-344. http://dx.doi.org/10.1016/S0037-0738(98)00145-6.

Eilu, P. 2012. Mineral deposits and metallogeny of Fennoscandia. Geological Survey of Finland, Special Papers 53. $403 \mathrm{p}$.

Eyles, N., Eyles, C.H. \& Miall, A.D. 1983. Lithofacies types and vertical prole models; an alternative approach to the description and environmental interpretation of glacial diamict and diamictite sequences. Sedimentology 30, 393410. http://dx.doi.org/10.1111/j.1365-3091.1983. tb00679.x

Fetter, C.W. 2001. Applied hydrogeology (4 ${ }^{\text {th }}$ Ed.). Prentice Hall, New Jersey. 598 p.

Freeze, A.R. \& Cherry, J.A. 1979. Groundwater. Prentice Hall, Netherlands. 604 p.

Gray, N.F. 1997. Environmental impact and remediation of acid mine drainage: a management problem. Environmental Geology 30, 62-71. http://dx.doi.org/ $10.1007 / \mathrm{s} 002540050133$.

Heikkinen, P.M., Korkka-Niemi, K. \& Salonen, V-P. 2002. Groundwater and surface water contamination in the area of the Hitura nickel mine, Western Finland. Environmental Geology 42, 313-329. http://dx.doi.org/ $10.1007 / \mathrm{s} 00254-002-0525-\mathrm{z}$.

Heikkinen, P.M., Noras, P., Salminen, R. 2008. Mining closure handbook. GTK, Espoo. 169 p.

Hiltunen, A. 1982. The Precambrian geology and skarn iron ores of the Rautuvaara area, Northern Finland. Bulletin of the Geological Survey of Finland 318, 133 p.

Hinton, M.J., Schiff, S.L. \& English, M.C. 1993. Physical properties governing groundwater flow in a glacial till catchment. Journal of Hydrogeology 142, 229-249. http:/ /dx.doi.org/10.1016/0022-1694(93)90012-X.

Hirvas, H. 1991. Pleistocene stratigraphy of Finnish Lapland. Bulleting of the Geological Survey of Finland 354, 125 p.

Johansson, P., Kujansuu, R. 2005. Pohjois-Suomen maaperä: maaperäkarttojen 1:400 000 selitys. Summary: Quaternary deposits of Northern Finland -Explanation to the maps of Quaternary deposits 1:400 000. Geological Survey of Finland, Espoo. 236 p.

Johansson, P., Lunkka, J.P., Sarala, P. 2011: Glaciation of Finland. In: Ehlers, J., Gibbard, P. L. \& Hughes, P. D. (Eds.), Quaternary glaciations - extent and chronology, a closer look, 105-116. Developments in Quaternary Science 15, Elsevier, Amsterdam.

Kearey, P., Brooks, M. \& Hill, I. 2002. An introduction to geophysical exploration. Blackwell Publishing, Oxford. $262 \mathrm{p}$.

Korvuo, E. 1982. Näytteenottoa raskaalla paineilmaporauskalustolla Tuohilehdossa, Rautuhelukassa ja Sivakkalehdossa 1980-1981. Rautaruukki Technical Report, Helsinki. $22 \mathrm{p}$.

Lunkka, J., Sarala, P. \& Gibbard, P. 2014. The Rautuvaara section, western Finnish Lapland revisited - new age constraints on the sequence indicate complex Scandinavian Ice Sheet history in Northern Scandinavia during the Weichselian stage. Boreas 44, 68-80. http:// dx.doi.org/10.1111/bor.12088.

Mattila, H. 1976. Rautuvaaran lähiympäristön kairaukset syksyllä 1975 - keväällä 1976 rautaruukin aineistot. Rautaruukki Technical Report, Helsinki. 27 p.

Murray, A. \& Wintle, A. 2000. Luminescence dating of quartz using an improved single-aliquot regenerative-dose protocol. Radiation Measurements 32, 57-73. http:// dx.doi.org/10.1016/S1350-4487(99)00253-X.

Närhi, P, Räisänen, M.L., Sutinen, M-L., Sutinen, R. 2012. Effect of tailings on wetland vegetation in Rautuvaara, a former iron-copper mining area in northern Finland. Journal of Geochemical Exploration 116-117, 60-65. http://dx.doi.org/10.1016/j.gexplo.2012.03.005.

Räisänen, M., Väisänen, U., Lanne, E., Turunen, P., Väänänen, J. 2006. Rautuvaaran kaivoksen rikastushiekka-altaan kemiallinen nykytila, vaikutukset pinta- ja pohjavesiin ja suositukset jälkihoidolle. Geological Survey of Finland, Espoo. 43 p.

Reynolds, J.M. 2011. An introduction to applied and environmental geophysics ( $2^{\text {nd }}$ Ed.). Wiley-Blackwell, Oxford. 710 p.

Rosas, J., Lopez, O., Missimer, T.M., Coulibaly, K.M., Dehwah, A.H.A., Sesler, K., Luijan, L.R., Mantilla, D. 2013. Determination of hydraulic conductivity from grain-size distribution for different depositional environments. Groundwater 52, 399-413. http://dx.doi.org/10.1111/ gwat. 12078.

Salomons, W. 1995. Environmental impact of metals derived from mining activities: processes, predictions, prevention. Journal of Geochemical Exploration 52, 5-23. http:// dx.doi.org/10.1016/0375-6742(94)00039-E.

Salonen, V-P. Moreau, J., Hyytinen, O. \& Eskola, K.O., 2014. Mid-Weichselian interstadial in Kolari, Western Finnish Lapland. Boreas 43, 627-638. http://dx.doi.org/10.1111/ bor. 12060 . 
SRK Consulting (U.K.) Limited. 2014. Technical report on the Hannukainen iron-copper-gold project, Kolari district, Finland. SRK Consulting (U.K.) Limited. 408 p. Avaliable at http://tupa.gtk.fi/valokuva/mineraalivara/References/ 462_Hannukainen/462_SRK_Hannukainen-TechnicalReport_2014.pdf.

Stephenson, D.A., Fleming, A.H. \& Mickelson, D.M. 1988. Glacial deposits. In: The geology of North America. Geological Society of America O-2, 301-314.

Thornton, I. 1996. Impacts of mining on the environment: some local, regional and global issues. Applied Geochemistry 11, 355-361. http://dx.doi.org/10.1016/08832927(95)00064-X.

Wessman, H., Salmi, O., Kohl, J., Kinnunen, P., Saarivuori, E., Mroueh, U.-M. 2014. Water and society: mutual challenges for eco-efficient and socially acceptable mining in Finland. Journal of Cleaner Production 84, 289-298. http://dx.doi.org/10.1016/j.jclepro.2014.04.026.

Winter, T.C. 1988. A conceptual framework for assessing cumulative impacts on the hydrology of non-tidal wetlands. Environmental Management 12, 605-620. http://dx.doi.org/10.1007/BF01867539.

Younger, P.L. 2007. Groundwater in the environment: an introduction. Blackwell publishing, Oxford. 390 p.

Younger, P.L. \& Wolkersdorfer, C. 2004. Mining impacts on the fresh water environment: Technical and managerial guidelines for catchment scale management. Mine Water and the Environment 23, 2-80. http://dx.doi.org/ 10.1007/s10230-004-0028-0. 